\title{
西藏柳区砾岩地质时代厘定的微体古植物 新证据及地质意义
}

\author{
韦利杰 ${ }^{(12)}$ ，刘小汉 ${ }^{(1)}$, 严富华 ${ }^{(3)}$, 麦学舜 ${ }^{(3)}$, 李广伟 ${ }^{(1)}$, 刘小兵 ${ }^{(1)}$, 周学君 ${ }^{(1)}$ \\ (1) 中国科学院青藏高原研究所, 北京 100085 ; \\ (2) 中国科学院研究生院, 北京 100049 ; \\ (3) 中国地震局地质研究所, 北京 100029 \\ *E-mail: weilj@itpcas.ac.cn
}

收稿日期: 2010-04-28; 接受日期: 2010-11-09

国家自然科学基金重点项目(批准号: 40631004)资助

\begin{abstract}
摘要柳区砾岩是印度与欧亚板块碰撞后产出的陆相山前磨拉石建造, 记录了新特提 斯洋构造演化后期的丰富地质与古环境信息. 本文对其中泥岩和泥质粉砂岩夹层进行了 孢粉学研究, 初步结果显示柳区砾岩中上部出现逐渐增多的渐新世孢粉组合, 说明柳区砾 岩建造的时代可上延至渐新世. 这套孢粉组合以落叶阔叶被子植物为主, 含一定量的松科 等针叶裸子植物和少量的常绿阔叶被子植物等组成的阔叶林或针阔叶混交林植被, 反映 了暖温带或温带的气候环境特征. 这一结果为深入研究新特提斯洋闭合后藏南古地理、古 气候、古生态和古海拔高度提供了新的重要制约.
\end{abstract}

关键词

藏南 雅鲁藏布江缝合带 柳区砾岩 孢粉组合 渐新世
青藏高原的隆升是印度板块向亚欧板块之下持 续俯冲, 新特提斯洋消亡, 进而发生陆-陆碰撞和地 壳缩短抬升的结果. 雅鲁藏布江蛇绿岩带则代表新 特提斯洋的残留洋壳, 与其两侧产出的中生代-新生 代火山-沉积建造共同构成雅鲁藏布江缝合带, 是晚 三叠世-古近纪新特提斯洋演化和青藏高原隆升综合 地质作用而形成的一条非常复杂的构造带 ${ }^{[1 ~ 23]}$. 雅江 蛇绿岩带两侧的沉积地层中记录了两大板块拼合过 程的丰富地质信息.

沿雅鲁藏布江缝合带出露至少两种类型的砾岩 质磨拉石 ${ }^{[24]}$. 产于雅鲁藏布江蛇绿岩带北侧的磨拉 石可分为海相和陆相两类, 一类是以白严纪末-始新 世曲下组和加拉孜组为代表的海相磨拉石 ${ }^{[25 ~ 28]}$; 另
一类是以渐新世末-早中新世卡拉斯组、秋乌组、大 竹卡组和罗布莎组组成的冈仁波齐砾岩系为代表的 陆相磨拉石 ${ }^{[24,29 \sim 32]}$. 产于雅鲁藏布江蛇绿岩带南侧 的磨拉石亦可分为海相和陆相两类, 海相磨拉石以 晚古新世-早始新世甲查拉组和者雅组为代表 ${ }^{[16,33,34]}$, 陆相磨拉石就是柳区砾岩 ${ }^{[29,35]}$, 也是本文讨论的重 点. 最新的研究认为, 沿雅鲁藏布江缝合带可能发生 过多次俯冲-碰撞事件, 新特提斯洋内也存在不止一 个俯冲系统, 雅鲁藏布江缝合带内至少保存了一个 新特提斯洋内岛弧复合体单元, 并在印度与亚洲碰

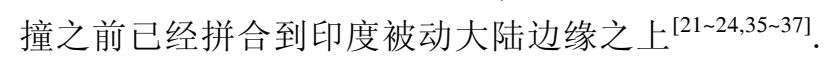
柳区砾岩的发育即与这一早期俯冲-碰撞事件有关, 该砾岩是碰撞后海相沉积结束, 地壳缩短隆升所形

英文引用格式: Wei L J, Liu X H, Yan F H, et al. Palynological evidence sheds new light on the age of the Liuqu Conglomerates in Tibet and its geological significance. Sci China Earth Sci, 2011, 54: 901-911, doi: 10.1007/s11430-010-4149-y 
成的一套山前磨拉石建造, 记录了新特提斯洋演化 后期的大地构造演化信息.

迄今为止, 对柳区砾岩形成时代的认识经历了 较长的历史过程. 20 世纪 60 70 年代, 在格龙村北的 砾岩中首次采集到植物大化石, 认为时代属于晚白 严世 ${ }^{[38]} .20$ 世纪 80 年代, 在拉孜县柳区群中上部发 现热带-亚热带植物印痕大化石, 并且认为该植物群 面貌时代为始新世中晚期 ${ }^{[39,40]}$. 近年来, 通过分析柳 区砾岩与相邻地区的接触关系及前人植物大化石资 料得出, 柳区砾岩的时代属于古近纪 ${ }^{[35]}$. 西藏自治区 地质调查院 ${ }^{1)}$ 在进行地质调查时在卡堆一带采集到 化石奇壳虫(未定种), 经中国科学院南京地质古生物 研究所鉴定认为其时代为古新世. 湖北省地质调查 院 ${ }^{2)}$ 在对拉孜县进行区域地质调查时在格龙普柳区 群采获植物印痕大化石及少量腹足类和双壳类化石, 认为地质时代属于古新世-始新世. Fang 等 ${ }^{[1,42]}$ 在柳 区村附近发现了植物印痕大化石 10 余种, 均为被子 植物, 且以双子叶植物居多, 认为时代属于始新世 中、晚期. 而尹集祥等 ${ }^{[29]}$ 研究表明, 柳区砾岩时代下 限不应低于始新世中晚期, 其时代上限要低于中新 世，即不排除包含渐新世的可能.

但是, 至今尚无人对柳区砾岩的泥岩和粉砂岩 夹层进行孢粉学研究, 上述涉及此段地层时代的厘 定大多依据植物印痕大化石. 韦利杰等 ${ }^{[43]}$ 首次从柳 区砾岩中提取出丰富的保存完好的孢粉化石, 并简 要讨论了古植被. 本文注重讨论这套地层的时代、古 环境及构造意义, 为这段地层的划分对比及地质年 代的确定提供新的重要古生物依据. 与植物大化石 相比, 孢粉地层记录相对较为连续, 在新生代古气候 及地层时代鉴定对比研究上有一定优势 ${ }^{[44]}$. 沉积岩 中的狍粉组合在某种程度上反映了该地区地质时期 的古植被, 而孢粉化石组合在研究植被总体特征等 方面可以弥补植物大化石保存记录不全的不足. 由 于古植被性质与状态是直接反映古气候、古地理地貌 及其他环境因子的真实指标, 因而孢粉植物群常用 于解释其来源地的气候环境变化过程. 更重要的是, 生物的特定进化规律及群落特征可以用来限定陆相 沉积地层的年代, 从而为研究高原隆升过程及相应
的古环境变化提供重要的时间制约.

\section{1 剖面描述}

柳区砾岩产出于雅鲁藏布江以南的特提斯喜马 拉雅构造-地层区, 主要分布于蛇绿岩南侧的柳区、卡 堆、曲美和白朗一带, 呈窄带状东西向展布. 砾岩带 西起拉孜镇, 东至白朗, 长约 $150 \mathrm{~km}$, 宽约数百米至 数千米, 出露面积约 $30 \mathrm{~km}^{2}$ (图 1). 本文采集标本的 剖面位于柳区砾岩带出露宽度最大的地段, 剖面全 长 $3.5 \mathrm{~km}$, 在该地区最大限度地控制了柳区砾岩的 产出层位. 剖面在热曲南岸出露长度很小, 自热曲北 岸 $\left(28^{\circ} 08^{\prime} 41^{\prime \prime} \mathrm{N}, 88^{\circ} 07^{\prime} 34^{\prime \prime} \mathrm{E}\right)$ 沿山沟向北攀升至与蛇绿 岩带逆冲断层交界处, 海拔 $4670 \mathrm{~m}$ (图 2). 柳区砾岩 带北侧被大竹曲地块蛇绿岩带的基性-超基性岩自北 向南高角度逆冲覆盖(图 2(a)). 剖面南端被亚姆卓混 杂岩中的三叠系修康群浅变质碎屑岩建造自南向北 逆冲超覆, 断层倾角近 $70^{\circ}$ (图 2(e)). 柳区砾岩层产状 以北倾为主, 局部可见开阔褶皱, 主体为正常沉积层 序(图 2(c)). 剖面北段(上部)可见典型开阔向斜构造, 向斜轴近水平东西走向, 两翼相向倾角 $15^{\circ} \sim 30^{\circ}$ (图 2 (b)). 向斜核部出露近水平的砾岩层最高层位. 向斜 北翼(剖面最北端)地层逐渐陡立, 局部被蛇绿岩向南 的逆冲牵引倒转. 柳区砾岩的主要岩性为杂色砾岩、 紫红色砂砾岩、红色砂岩夹泥质砂岩和粉砂质泥岩. 薄层灰绿色泥质砂岩(图 2(d)) 和粉砂质泥岩分布于底 部和上部.

柳区砾岩沉积于印度大陆北缘与新特提斯洋内 一个晚侏罗世-白严纪岛弧之间的斜滑盆地内, 其沉 积环境是陆地和浅水环境 ${ }^{[35]}$. 柳区砾岩的沉积方式 突变及相变不连续, 说明柳区砾岩为快速沉积 ${ }^{[35]}$. 剖 面岩性整体较粗, 我们在砾岩夹层中的泥质砂岩和 粉砂质泥岩采集样品 16 份(图 2).

\section{2 讨论}

所有样品中都含有十分丰富的孢粉, 每个样品 都鉴定到 200 300 粒, 共鉴定出 52 个形态属. 每个样 品主要的狍粉类型及百分比参见图 3, 主要属种的图 版见图 4, 详细统计数据参见韦利杰等 ${ }^{[43]}$.

1) 西藏自治区地质调查院. 1:250000 区域地质调查专题报告(日喀则市幅). 2002

2) 湖北省地质调查院. 1:250000 区域地质调查专题报告(拉孜县幅). 2003 


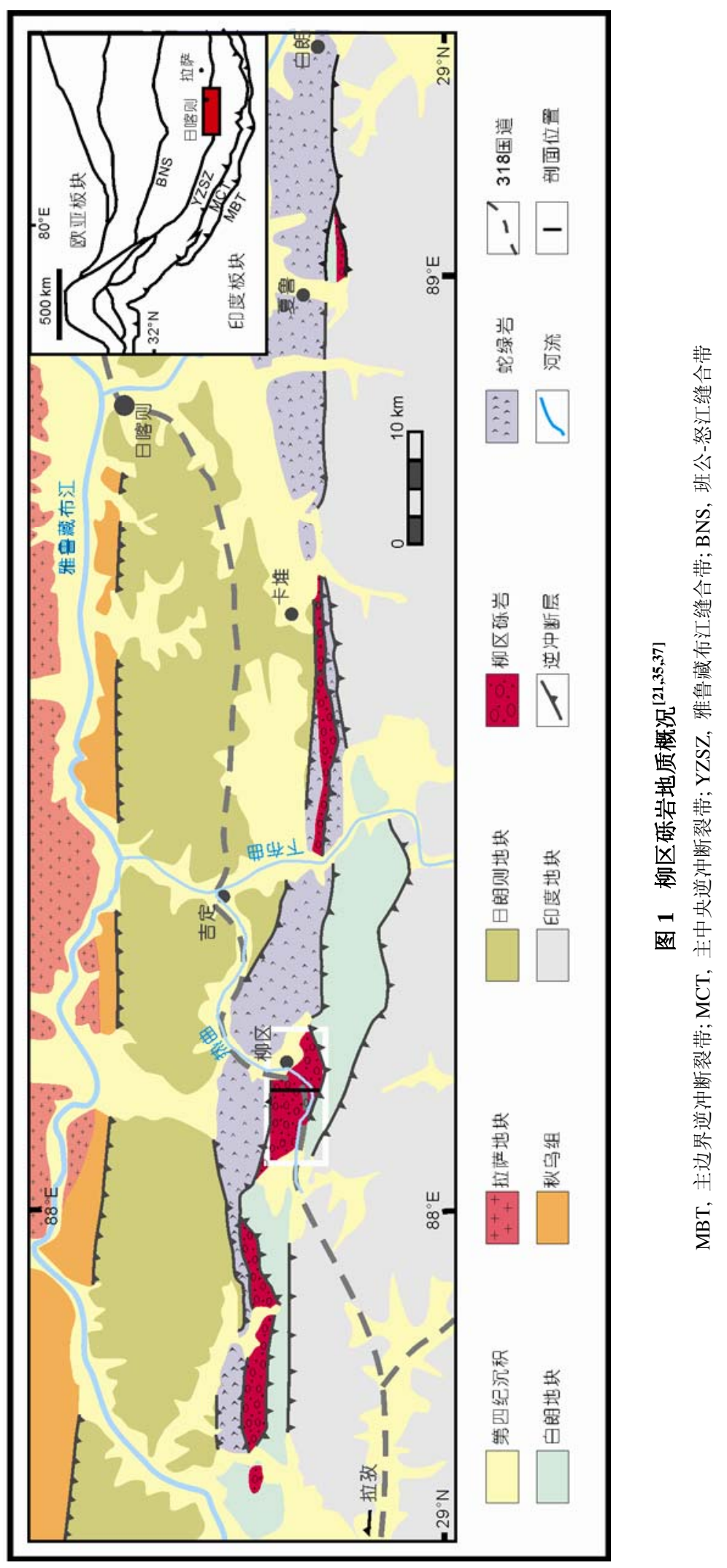




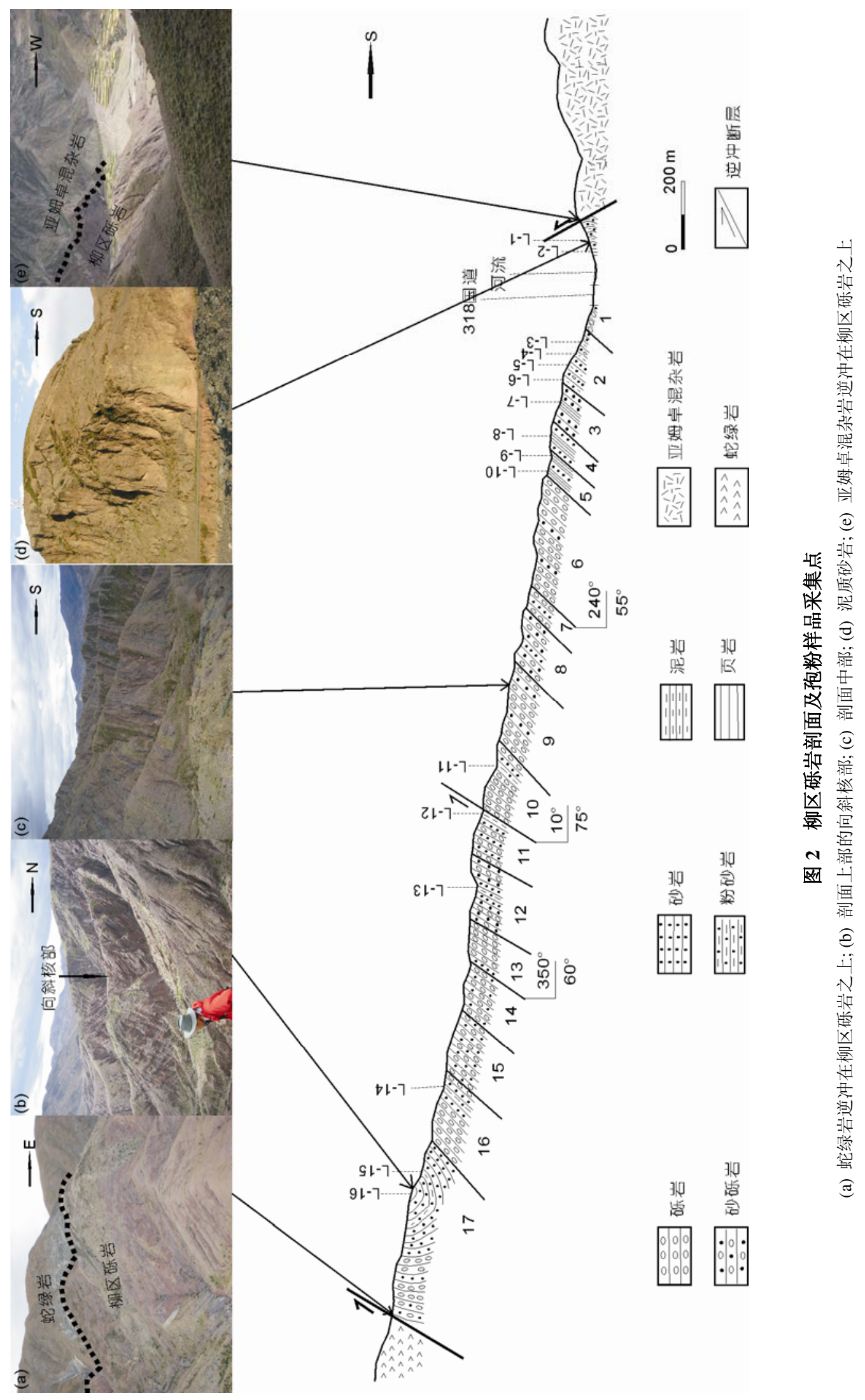




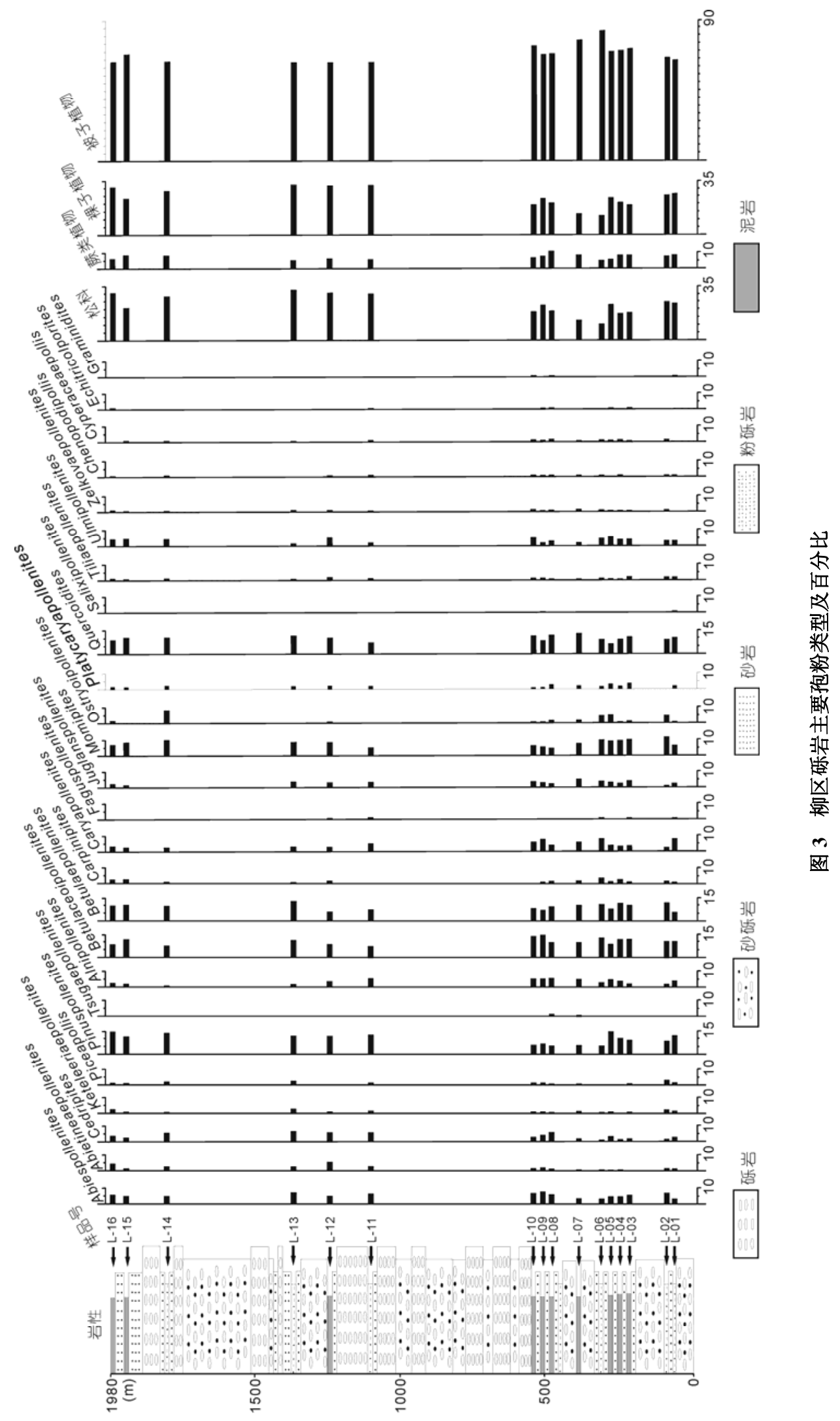



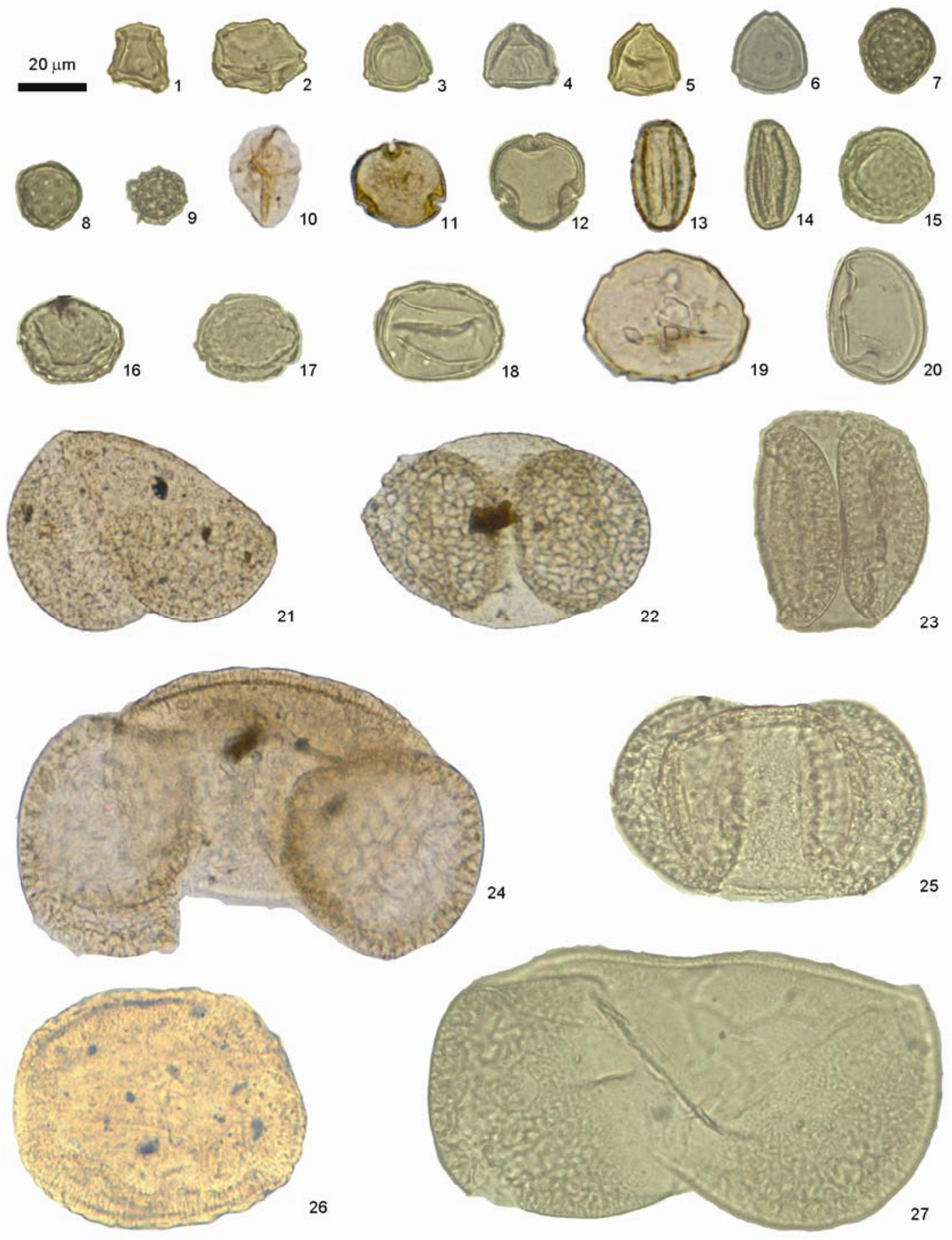

图 4 柳区砾岩主要孢粉类型

1. Alnipollenites metaplasmus (Potonie) Potonie, 1960; 2. Alnipollenites verus (Pot.) Pot., 1960; 3. Betulaceoipollenites bituitus (Pot.) Pot., $1960 ; 4$. Betulaepollenites microrugusus Song et Zhu, 1985; 5. Ostryoipollenites sp.; 6. Momipites coryloides Wodehouse, 1933; 7, 8. Chenopodipollis spp.; 9. Echitricolporites minor Song et Zhu, 1985; 10. Graminidites sp.; 11, 12. Tiliaepollenites spp.; 13. Quercoidites cf. Q. densus (Pflug) Song et Zheng, 1978; 14. Quercoidites henrici (Pot.) Pot., Thoms. et Their., 1950; 15, 16. Ulmipollenites spp.; 17. Zelkovaepollenites thiergarti Nagy, $1969 ; 18$. Juglanspollenites sp.; 19. Juglanspollenites rotundus Ke et Shi, 1978; 20. Cyperaceaepollis sp.; 21. Cedripites sp.; 22, 25. Pinuspollenites spp.; 23. Abietineaepollenites sp.; 24. Abiespollenites sibiriciformis (Zakl.) Krutzsch, 1971; 26. Tsugaepollenites viridifluminipites (Wodehouse) Pot., 1958; 27. Piceapollis praemarianus Krutzsch, 1971; 比例尺 $=20 \mu \mathrm{m}$ 


\section{1 地质时代讨论}

柳区砾岩孢粉组合以被子植物花粉占优势, 其 中又以具孔类为主，包括桦木科、胡桃科、山毛榉科、 榆科及椴科等. 这些分子均为国内外新生代常见分 子. 如桦木科植物为泛北极分子, 广泛见于世界各地 古近纪中晚期, 尤以晚期最为繁盛 ${ }^{[45]}$. 张一勇 ${ }^{[46]}$ 总 结前人研究资料认为, 晚始新世之后胡桃科花粉表 现为现代性及 Juglanspollenites 和 Platycaryapollenites 发展起来. 在本孢粉组合中, 含量较高的 Caryapollenites 与现代植物 Carya tonkinensis 的花粉 比较相似, Juglanspollenites 和 Platycaryapollenites 有 一定含量. Momipites 中主要为地质时代延续较长的 Momipites coryloides, 从古新世一直延续到中新世, 广泛见于世界各地古近纪中、晚期, 尤以晚期最为繁 盛 ${ }^{[47]}$. 榆科以个体较大的 Ulmipollenites 和 Zelkovaepollenites 为主, 古近纪早期常见的 Ulmipollenites minor 和 Ulmoideipites 几乎未见. 从本文研究的微体 化石组合看, 整个狍粉组合中未见任何白严纪及古 近纪早期常见的鹰粉类和正型粉类等分子，因而可 以确切地排除本地区柳区砾岩归属晚白严世和古新 世的可能性. 在本狍粉组合中典型的亚热带-热带分 子仅少量出现, 热带-亚热带被子植物是古近纪早中 期的常见分子. 由于生物进化的连续性, 在古近纪晚 期也应含有少量古近纪早中期常见的亚热带-热带分 子. 据上分析, 柳区砾岩沉积时期的古植被特征是以 桦木科、胡桃科、山毛榉科和榆科等温带类型的落叶 阔叶类植物为主, 该剖面出露的砾岩应为古近纪晚 期.

柳区砾岩孢粉组合中的裸子植物花粉是以 Abietineaepollenites, Pinuspollenites, Cedripites, Abiespollenites 及少量 Tsugaepollenites 等松科花粉为 主，以具双气囊类居多. 松科花粉在整个组合中平均 占孢粉总数的 $22.48 \%$, 含量已经较高. Abiespollenites 在我国柴达木盆地直到渐新世下干柴沟组才开始出 现 $^{[45]}$. 该组合中零星见到在中新世才普遍存在, 渐新 世仅少量或零星出现的 Tsugaepollenites ${ }^{[32,45,48]}$. 因此, 柳区砾岩的地质时代应为渐新世.

愁科、菊科、禾本科及莎草科等草本植物在地史 中均出现较晚, 一般多始现于古近纪, 至新近纪才比 较繁盛. 这些草本植物花粉在该剖面虽均见有, 但皆
数量不多, 特别是菊科及菊科之蒿粉属花粉. 菊科花 粉一般出现于古近纪晚期, 在渐新世仅零星出现, 直 至中新世才在世界各地普遍分布. 在本孢粉组合中 发现的少量菊科花粉为早期的菊科 Echitricolporites 花粉, 而未见菊科 Artemisiaepollenites 之花粉. Artemisiaepollenites 花粉到中新世才开始出现，是划分渐 新世和中新世的重要依据. 莎草科花粉最早的化石 发现于始新世中期 ${ }^{[49]}$, 但在新近纪才有较大的发展. 黎科及菊科等草本植物花粉在本组合中未形成优势 种群, 只是零星出现, 且没有见到更为进化的类型. 基于这些草本植物及其花粉的地史分布, 无疑亦可 作为确定及划分地层时代之依据. 据此可见, 该砾岩 的地质时代可能属于渐新世.

在一定地理区域范围内, 相同地质时代的古植 被及古气候一般也是相同或相似的, 可进行比较. 据 研究, 在我国西北及西南地区渐新世地史时期之古 植被也多是以华等落叶阔叶被子植物为主及含一定 量的松组成的阔叶林或针阔叶混交林，气候温暖湿 润, 这样性质的古植被及古气候也可见于该剖面之 沉积时期, 看来该剖面的地质时代可拟定为渐新世. 我国渐新世孢粉组合比较丰富, 东部及南部地区代 表性的有江苏戴南组 ${ }^{[50]}$ 、江西清江盆地临江组 ${ }^{[51]}$ 、 湖北江汉平原潜江组下段 ${ }^{[52]}$ 、广东雷州半岛涠洲 组 ${ }^{[53]}$ 、广西百色盆地伏平组 ${ }^{[54]}$ 和广东三水盆地华涌 组 ${ }^{[55]}$. 这些组合中落叶阔叶林占重要地位; 裸子植 物有多有少，但松科和杉科花粉在裸子植物中占优 势, 热带和亚热带成分频繁出现, 说明渐新世东部及 南部地区较本地区温暖潮湿. 造成本组合与上述孢 粉组合存在差异的原因, 可能是渐新世青藏高原独 特的地貌特征已开始显现. 又该剖面沉积时期之古 植物特征及其古气候性质与皆属渐新世同期异相的 青海柴达木盆地下干柴沟组 ${ }^{[45]}$ 、西藏伦坡拉盆地伦坡 拉群下部 ${ }^{[56]}$ 及东昆仑造山带西段万宝沟岩群 ${ }^{[48]}$ 沉积 时期之古植被及古气候的特性亦基本相同及皆可以 进行对比，据此亦可认为该剖面柳区砾岩的地质时 代应定为渐新世. 柴达木盆地下干柴沟组以被子植 物花粉为主, 如 Quercoidites, Meliaceoidites 及桦科花 粉等; 松柏类具气囊类花粉占 $27.97 \%$, 其中 Piceapollis 占 $13.67 \%$, Tsugaepollenites 和 Abiespollenites 开始出现; Ephedripites 占 $13.81 \%$; 草本植物花 
粉没有形成优势种 ${ }^{[45]}$. 东昆仑造山带西段万宝沟组 渐新世孢粉组合特征是被子植物占 $68 \%$, 裸子植物 占 $26 \%$, 偋类植物狍子含量较少; 其中被子植物中落 叶阔叶植物花粉居主导地位, Caryapollenites 含量高, 其次为 Betulaceoipollenites, Momipites 和 Ulmipollenites 等, 草本植物频繁出现; 裸子植物花粉以松科 为主(接近 20\%), Ephedripites 占 7\% ${ }^{[48]}$. 上述两个孢 粉组合中 Ephedripites 含量高, 说明当时这两个地区 比本地区干旱. 伦坡拉盆地伦坡拉组下部的狍粉组 合是以具囊的松柏类超过半数为特征, 被子植物以 Salixipollenites, 胡桃科和桦科等为主 ${ }^{[56]}$. 本组合中 的松柏类含量不如上述组合中的高, 可能是因为本 地区当时所处的纬度较低, 气候相对较温暖的缘故.

始新世-渐新世之交发生全球变冷事件 ${ }^{[57,58]}$, 过 渡到渐新世早期气温下降 ${ }^{[59]}$. 植被成分对这一变冷 事件的反映为热带-亚热带植物逐渐减少, 温带成分 增加 ${ }^{[60,61 ~ 63]}$. 渐新世时期北半球气温逐渐降低, 这在 北美、欧洲和亚洲的地层中可以找到化石证据. 许多 地区渐新世都出现了以温带落叶阔叶林及针叶林花 粉为主的狍粉组合, 如德国褐煤层 ${ }^{[64]}$ 、印度喜马偕

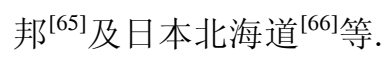

综上所述, 柳区砾岩的沉积时代可以初步定为 渐新世. 由于该剖面底部未出露完整, 所以不排除柳 区砾岩含有始新世沉积的可能性. 该剖面顶部为向 斜核部，未见顶，亦不排除包括中新世的可能.

\section{2 古环境分析}

柳区砾岩狍粉植物群被子植物中华科、胡桃科、 山毛榉科和榆科等温带落叶阔叶树花粉占绝对优势 表明这一时期的气候是较温湿的, 而未见反映热湿 气候的杉粉和棕榈粉等被子植物花粉, 栗粉、黄杞 粉、桃金娘粉、漆树粉、枫杨粉和紫树粉等指示热带 和亚热带的气候分子含量低. 冷杉属、云杉属、雪松 属和铁杉属等温带高山针叶树花粉在裸子植物中占 有一定的含量, 它们都是耐寒喜湿分子. 冷杉属和云 杉属的高含量指示当时的气候又冷又湿 ${ }^{[67]}$. 本组合 中典型干旱植物分子麻黄科和藜科及菊科等花粉含 量少, 指示样品所在的层位沉积时的气候并不干旱, 总体反映了暖和较湿或温和较湿的气候, 主要为暖 温带或温带的环境.
松科是生长在高海拔地区的植物, 本组合中松 科平均可达 $22 \%$, 说明当时的青藏高原已经有一定 的高度生长这些山地针叶林. 以桦科、胡桃科、山毛 榉科和榆科等为主的温带落叶阔叶林生长在低山或 丘陵地区, 冬青科和桃金娘科等少量的亚热带和热 带树种杂生其中. 地势低洼地区林下生长着偋类植 物及少量的灌木和草本植物. 综上所述, 藏南柳区群 狍粉组合特征反映的古植被是以温带型为主的落叶 阔叶林植物和以松科为主的山地针叶林植物, 林下 植被为硕类植物及少量的灌木和草本植物.

\section{3 地质意义及结论}

雅鲁藏布江缝合带柳区砾岩地质时代的确定对 于研究印度板块和欧亚板块碰撞时代及碰撞后的大 地构造演化具有重要意义. 冈仁波齐砾岩形成于渐 新世末-早中新世 ${ }^{[21,32]}$, 与本文研究的柳区砾岩显然 属于不同的地质时期, 说明它们是由不同的俯冲-碰 撞事件形成的, 进一步证实了新特提斯洋内存在不 止一套俯冲系统. 由于未能见到柳区砾岩最底部岩 层, 所以目前的地质时代并不一定能确定碰撞作用 开始-海相沉积结束的最早时代, 但可以肯定在这个 地质时期印度板块已经与特提斯洋内岛弧发生了碰 撞作用. 柳区砾岩中缺乏来自雅鲁藏布江缝合带北 侧冈底斯弧的物质, 暗示该砾岩的形成可能早于印 度和欧亚板块碰撞和新特提斯最终闭合的时期 ${ }^{[35]}$. 雅鲁藏布江缝合带南侧海相地层古新世-始新世早期 甲查拉组的研究表明, 藏南地区的封闭时间应在晚 始新世普里阿邦期之后 ${ }^{[34,68]}$, 冈仁波齐砾岩的研究 认为印度板块和欧亚板块碰撞应早于渐新世末-早中 新世 ${ }^{[21]}$. 因此可从上述分析得出, 印度板块与欧亚板 块的陆-陆碰撞不会早于渐新世, 这与 Aitchison 等 ${ }^{[22]}$ 通过研究印度次大陆的相对位置及藏南沉积岩记录 的信息得出的陆-陆碰撞开始于 $34 \mathrm{Ma}$ 基本一致.

通过对藏南柳区砾岩孢粉组合特征的分析, 可 得出如下结论:

(1) 柳区砾岩含有渐新世沉积.

(2) 藏南柳区砾岩狍粉组合特征反映了以温带 类型的落叶阔叶被子植物为主及含一定量的松科等 针叶裸子植物和少量常绿阔叶被子植物等的暖温带 或温带阔叶林或针阔叶混交林植被. 


\section{参考文献}

1 Gansser A. Geology of the Himalayas. Hoboken: John Wiley and Sons Ltd, 1964. 289

2 Nicolas A, Girardeau J, Marcoux J, et al. The Xigaze ophiolite (Tibet): A peculiar oceanic lithosphere. Nature, 1981, 294: 414-417

3 Tapponnier P, Mercier J, Proust F, et al. The Tibetan side of the India-Eurasia collision. Nature, 1981, 294: 405-410

4 Burg J P, Chen G. Tectonics and structure zonation of southern Tibet, China. Nature, 1984, 311: 219-223

5 Girardeau J, Mercier J, Zao Y. Structure of the Xigaze ophiolite, Yarlung Zangbo suture zone, southern Tibet, China: Genetic implications. Tectonics, 1985, 4: 267-288

6 Searle M P, Windley B F, Coward M P, et al. The closing of Tethys and the tectonics of the Himalaya. Geol Soc Am Bull, 1987, 98: $678-701$

7 Einsele G. The Xigaze forearc basin: Evolution and facies architecture (Cretaceous, Tibet). Sediment Geol, 1994, 90: 1-32

8 Dürr S B. Provenance of Xigaze fore-arc basin clastic rocks (Cretaceous, south Tibet). Geol Soc Am Bull, 1996, 108: 669-684

9 Rowley D B. Age of initiation of collision between India and Asia: A review of stratigraphic data. Earth Planet Sci Lett, 1996, 145: 1-13

10 肖序常, 王军. 青藏高原构造演化及隆升的简要评述. 地质论评, 1998, 44: 372-381

11 许靖华, 孙枢, 王清晨, 等. 中国大地构造相图(1:4000000). 北京: 科学出版社, 1998. 1-155

12 Yin A, Harrison T M. Geologic evolution of the Himalayan-Tibetan orogen. Annu Rev Earth Planet Sci, 2000, 28: 211-280

13 Yin A. Cenozoic tectonic evolution of the Himalayan orogen as constrained by along-strike variation of structural geometry, exhumation history, and foreland sedimentation. Earth Sci Rev, 2006, 76: 1-131

14 潘桂棠, 王立全, 尹福光, 等. 从多岛弧盆系研究实践看板块构造登陆的魅力. 地质通报, 2004, 23: 933-939

15 潘桂棠, 王立全, 朱弟成. 青藏高原区域地质调查中几个重大科学问题的思考. 地质通报, 2004, 23: 12-19

16 Ding L, Kapp P, Wan X. Paleocene-Eocene record of ophiolite obduction and initial India-Asia collision, south central Tibet. Tectonics, 2005, 24: TC3001, doi: 10.1029/2004TC001729

17 许志琴, 杨经绥, 李海兵, 等. 青藏高原与大陆动力学一一地体拼合、碰撞造山及高原隆升的深部驱动力. 中国地质, 2006, 33: $221-238$

18 Liu X H. Structural feature of Yarlung Zangbo ophiolite zone and its tectonic significance. The 20th Himalaya-Karakoram-Tibet Workshop. Geol Alpine Mem, 2005, 44: 121

19 Liu X H. Re-examination of the Yarlung Zangbo Suture Zone: An alternative tectonic model. Proceeding of the Himalaya-Karakunlun-Tibet Symposium, Hongkong, 2007. 63

20 刘小汉, 琚宜太, 韦利杰, 等. 再论雅鲁藏布江缝合带构造模型. 中国科学 D 辑: 地球科学, 2009, 39: 448-463

21 Aitchison J C, Abrajevitch A, Ali J R, et al. New insights into the evolution of the Yarlung Tsangpo suture zone, Xizang (Tibet), China. Episodes, 2002, 25: 90-94

22 Aitchison J C, Ali J R, Davis A M. When and where did India and Asia collide? J Geophys Res-Solid Earth, 2007, 112: B05423, doi: $10.1029 / 2006 J B 004706$

23 Aitchison J C, Davis A M. Evidence for the multiphase nature of the India-Asia collision from the Yarlung Tsangpo suture zone, Tibet. In: Malpas J G, Fletcher C J N, eds. Aspects of the Tectonic Evolution of China. Geol Soc Spec Publ, 2004, 226: 217-233

24 Davis A M, Aitchison J C, Badengzhu B, et al. Conglomerates record the tectonic evolution of the Yarlung-Tsangpo suture zone in southern Tibet. Geol Soc Spec Publ, 2004, 226: 235-246

25 章炳高, 穆西南. 西藏雅鲁藏布江以北海相第三系的发现. 地层学杂志, 1979, 3: 65-66

26 刘成杰, 尹集祥, 孙晓兴, 等. 西藏南部日喀则弧前盆地非复理石型海相上白严统-下第三系. 中国科学院地质研究所集刊, 1988, 3: $130-157$

27 万晓樵, 孙立新, 刘文灿, 等. 西藏雅鲁藏布江缝合带地层. 北京: 地质出版社, 2007. 1-119

28 Li J G, David J B, Zhang Y Y. Palynological indications of environmental changes during the Late Cretaceous-Eocene on the southern continental margin of Laurasia, Xizang (Tibet). Palaeogeogr Palaeoclimatol Palaeoecol, 2008, 265: 78-86 
29 尹集祥, 孙晓兴, 孙亦因, 等. 西藏南部日喀则地区双磨拉石带磨拉石岩系的地层学研究. 中国科学院地质研究所集刊, 1988, 3: $158-176$

30 Miller C, Schuster R, Klötzli U, et al. Late Cretaceous-Tertiary magmatic and tectonic events in the Transhimalaya batholith (Kailas area, SW Tibet). Schweiz Mineral Petrogr Mitt, 2000, 80: 1-20

31 Chan A O K, Aitchison J C, Badengzhu B, et al. Miocene collision-related conglomerates near Dazhuqu and Xigaze, Yarlung Tsangpo suture zone, Tibet. Himalayan J Sci, 2004, 2: 112

32 李建国. 西藏新生代秋乌组狍粉化石的发现及其初步研究. 微体古生物学报, 2004, 21: 216-221

33 丁林, 来庆洲. 冈底斯地壳碰撞前增厚及隆升的地质证据: 岛弧拼贴对青藏高原隆升及扩展历史的制约. 科学通报, 2003, 48: $836-842$

34 李国彪, 万晓樵, 刘文灿, 等. 雅鲁藏布江缝合带南侧古近纪海相地层的发现及其构造意义. 中国科学 D 辑: 地球科学, 2004, 34: 228-240

35 Davis A M, Aitchison J C, Badengzhu B, et al. Paleogene island arc collision-related conglomerates, Yarlung-Tsangpo suture zone, Tibet. Sediment Geol, 2002, 150: 247-273

36 Aitchison J C, Badengzhu B, Davis A M, et al. Remnants of a Cretaceous intra-oceanic subduction system within the Yarlung-Zangbo suture (southern Tibet). Earth Planet Sci Lett, 2000, 183: 231-244

37 Aitchison J C, Davis A M, Badengzhu B, et al. New constraints on the India-Asia collision: The Lower Miocene Gangrinboche conglomerates, Yarlung Tsangpo suture zone, SE Tibet. J Asian Earth Sci, 2002, 21: 251-263

38 郭双兴. 珠穆朗玛峰地区日喀则群的植物化石. 珠穆朗玛峰地区科学考察报告(1966-1968). 古生物(第一分册). 北京: 科学出版社, 1975. 411-423

39 Tao J R. The Paleogene flora and palaeoclimate of Liuqu formation in Xizang. In: Whyte P, Aigner J S, Jablonski N G, et al, eds. The Paleoenvironment of East Asia from the mid-Tertiary. Occasional Papers and Monographs-Centre of Asian Studies. Hong Kong: University of Hong Kong Press, 1988. 520-522

40 陶君容. 西藏拉孜县柳区组植物化石组合及古气候意义. 中国科学院地质研究所集刊, 1988, 3: 223-238

41 Fang A M, Yan Z, Liu X H, et al. The age of the plant fossil assemblage in the Liuqu Conglomerate of southern Tibet and its tectonic significance. Prog Nat Sci, 2006, 16: 55-64

42 方爱民, 闰臻, 刘小汉, 等. 藏南柳区砾岩中古植物化石组合及其特征. 古生物学报, 2005, 44: 435-445

43 韦利杰, 刘小汉, 严富华, 等. 藏南古近系柳区砾岩狍粉化石的发现及初步研究. 微体古生物学报, 2009, 26: 249-260

44 朱怀诚, 欧阳舒. 孢子花粉与植物大化石: 地质纪录的差异及其古植物学意义. 古生物学报, 2005, 44: 161-174

45 宋之琛, 朱宗浩, 巫礼玉, 等. 柴达木盆地第三纪狍粉学研究. 北京: 石油工业出版社, 1985. 1-297

46 张一勇. Momipites 的几个先驱种在我国下第三系的发现. 古生物学报, 1990, 29: 300-308

47 张一勇, 王可德, 刘金陵, 等. 东海陆架盆地西南部始新世狍粉. 微体古生物学报, 1990, 7: 389-402

48 郭宪璞, 王乃文, 丁孝忠, 等. 东昆仑造山带西段万宝沟岩群古近纪孢粉组合的发现及其地质意义. 中国科学 D 辑: 地球科学, 2005, 35: 1156-1164

49 Tiffney B H. Perspectives on the origin of the floristic similarity between eastern Asia and eastern America. J Arnold Arbor Harv, 1985, 66: 73-94

50 宋之琛，郑亚惠，刘金陵，等. 江苏地区白严纪-第三纪狍粉组合. 北京：地质出版社, 1981. 1-268

51 何月明, 孙湘君. 江西清江盆地下第三系孢子花粉的初步研究 I . 植物学报, 1977, 19: 72-82

52 李曼英, 宋之琛, 李再平. 江汉平原白严-第三纪的几个孢粉组合. 中国科学院南京地质古生物研究所集刊, 1978, 9: 1-60

53 张一勇. 雷州半岛第三纪狍粉. 古生物学报, 1981, 20: 449-458

54 杨荣玉. 广西百色盆地第三系孢粉组合及时代. 广西地质, 1994, 7: 1-11

55 宋之琛, 李曼英, 钟林. 广东三水盆地白严纪-早第三纪孢粉组合. 北京: 科学出版社, 1986. 1-170

56 宋之琛, 刘耕武. 西藏东北部早第三纪狍粉组合及其古地理意义. 西藏古生物(第五分册). 北京: 科学出版社, 1982. 165-190

57 Bowen G J. Palaeoclimate: When the world turned cold. Nature, 2007, 445: 607-608

58 Lear C H, Bailey T R, Pearson P N, et al. Cooling and ice growth across the Eocene-Oligocene transition. Geology, 2008, 36: 251-254

59 Katz M E, Miller K G, Wright J D, et al. Stepwise transition from the Eocene greenhouse to the Oligocene icehouse. Nat Geosci, 2008 , 1: 329-334

60 张一勇. 中国早第三纪狍粉植物群纲要. 古生物学报, 1995, 34: 212-227

61 Dupont-Nivet G, Hoorn C, Konert M. Tibetan uplift prior to the Eocene-Oligocene climate transition: Evidence from pollen analysis of the 
Xining Basin. Geology, 2008, 36: 987-990

62 Dupont-Nivet G, Krijgsman W, Langereis C G, et al. Tibetan Plateau aridification linked to global cooling at the Eocene-Oligocene transition. Nature, 2007, 445: 635-638

63 William C E, Thomas E Y. Palynomorph biozones in the context of changing paleoclimate, Middle Eocene to Lower Oligocene of the Northwest Gulf of Mexico. Palynology, 2000, 24: 177-186

64 Krutzsch W. Mikropalaeontogische (Sporenpalaontologische) Untersuchungen in der Braunkohle des Geiseltales. Geologie, 1959, 21-22: $1-425$

65 Mathur Y K. Cenozoic palynofossils, vegetation, ecology and climate of the north and northwestern Subhimalayan Region, India. In: Whyte R O, ed. The Evolution of the East Asian Environment, Vol. 2. Hong Kong: Center of Asian Studies, University of Hong Kong, 1984. 504-512

66 Kiyoshi T. Palaeogene pollen assemblages and zonation of Japan. J Jpn Palynol Soc, 1983, 29: 1-18

67 Sun X J, Wang P X. How old is the Asian monsoon system?-Palaeobotanical records from China. Palaeogeogr Palaeoclimatol Palaeoecol, 2005, 222: 181-222

68 Li G B, Wan X Q. Eocene microfossil in southern Tibet and the final closing of the Tibet-Tethys. J Stratigr, 2003, 27: 99-108 